\title{
Reversibility of acute renal failure in elderly patients with the nephrotic syndrome
}

\author{
Martin Searle, Cyrus Cooper, Jonathan Elliman, Rodney Dathan and Angus \\ Maciver
}

Departments of Medicine and Pathology, Southampton University Hospitals, Southampton, UK.

\begin{abstract}
Summary: Acute renal failure may occur in the nephrotic syndrome due to minor glomerular changes, especially in the elderly. We describe five cases and review the literature. Previous renal damage due to ischaemia and drugs may be important in pathogenesis. We stress the importance of active management of these cases, as the renal lesions are reversible and recovery can be expected.
\end{abstract}

\section{Introduction}

Acute oliguric renal failure occurring in patients with the nephrotic syndrome due to minor glomerular changes poses an unusual and difficult management problem. There is considerable variation in the natural history of the condition. The glomerular lesion cannot be held to account for the severity of the renal failure and therefore interest has been stimulated in other mechanisms, including toxic and ischaemic tubular damage and renal vein thrombosis.

We describe in detail a patient with this syndrome, together with four other cases identified from our biopsy records. The literature is reviewed and the pathological mechanisms and management are discussed.

\section{Case report}

A 77 year old man presented with a 2 week history of ankle oedema and exertional dyspnoea due to the nephrotic syndrome. He had been commenced on frusemide $80 \mathrm{mg} / \mathrm{d}$ and spironolactone $75 \mathrm{mg} / \mathrm{d} 1$ week previously. On examination the blood pressure was $170 / 100 \mathrm{mg} \mathrm{Hg}$ with no postural fall. Investigations showed a normal blood count, blood urea $17.1 \mathrm{mmol} / 1$ and serum creatinine $233 \mu \mathrm{mol} / 1$. Urine protein was $21.3 \mathrm{~g}$ in $24 \mathrm{~h}$ and serum albumin $24 \mathrm{~g} / \mathrm{l}$. Liver function and immunological tests were normal. Ultrasound showed a solid mass at the upper pole of the right kidney, confirmed on intravenous urography, which was presumed to be a renal adenocarcinoma. Renal

Correspondence: M. Searle, B.Sc., B.M., M.R.C.P. (UK) Royal South Hants Hospital, Graham Road, Southampton, UK.

Accepted: 31 January 1985 venography demonstrated a tumour venous circulation but the renal veins were patent.

During the first week following admission the dose of frusemide was raised to $160 \mathrm{mg} / \mathrm{d}$ but he became oliguric. Intravenous methylprednisolone $1 \mathrm{~g}$ on alternate days was given for $10 \mathrm{~d}$ without response. Renal biopsy $6 \mathrm{~d}$ after admission showed mild mesangial proliferative glomerulonephritis and proximal tubular damage. Electron microscopy showed severe podocyte loss and tubular vacuolation (Figures 1 and 2). No immune proteins were detected.

All drugs were withdrawn and peritoneal dialysis was carried out for $5 \mathrm{~d}$. He tolerated dialysis poorly and remained anuric. A second renal biopsy, $8 \mathrm{~d}$ after the first, showed the same glomerular lesion but with less severe tubular changes. Peritoneal dialysis was started for a further $5 \mathrm{~d}$ when urine output started to recover and reached $2.5 \mathrm{l} / \mathrm{d}$ by 1 month, with a normal serum creatinine.

The diagnosis of renal adenocarcinoma remains a radiological one as, after discussion with the patient, surgery was not carried out.

\section{Discussion}

Acute oliguric renal failure occurring during the course of nephrotic syndrome is usually associated with severe disease processes such as crescentic or necrotizing glomerulonephritis and is often irreversible. However, it is also recognized that oliguric renal failure can complicate the nephrotic syndrome in which the glomerular lesion of minimal change or mild mesangial proliferative glomerulonephritis, is not severe enough to explain the change in renal function.

Chamberlain et al., (1966) described 9 patients with 


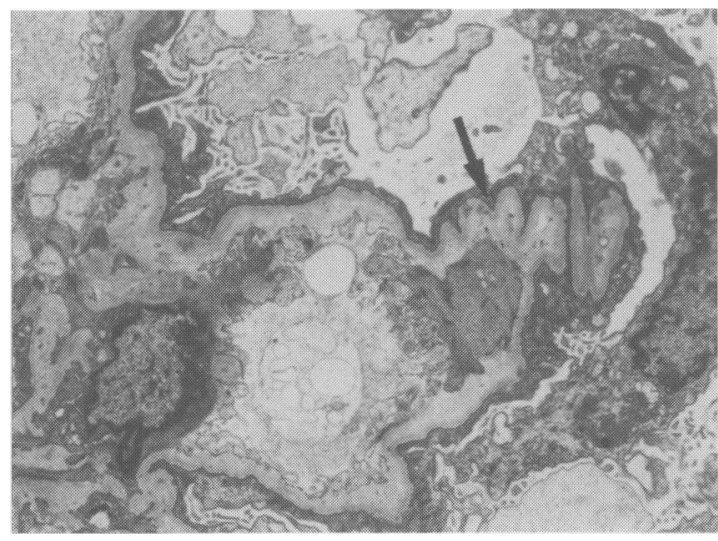

Figure 1 The glomerular capillary loop is partly collapsed and shows basement membrane wrinkling (arrow) due to reduced glomerular perfusion. Electronmicrograph $\times 3600$.

idiopathic nephrotic syndrome who developed renal failure, of whom 4 had minor glomerular changes. The subsequent literature describes a total of 36 cases (Table I) in which there has been considerable variation in outcome. Renal failure was reversible in 22 $(61 \%)$ with a period of oliguria for 1 week to 6 months. Renal death occurred in $13(37 \%)$ patients.

A review of our own renal biopsy records over a 10 year period revealed four other cases (Table II). Minimal change nephritis was present in two and mild mesangial proliferative nephritis in two. Peritoneal dialysis was required in two patients but one, not so treated because of his age and reluctance, died. It was the striking and dominant tubular damage present in his post-mortem renal tissue that prompted us to be more aggressive in the case described above.

The pathogenesis of acute renal failure in these patients is unclear. Hypovolaemia must always be excluded by clinical examination at presentation and throughout treatment with diuretics, the urea/creatinine ratio may be a useful laboratory aid in this (Kopple

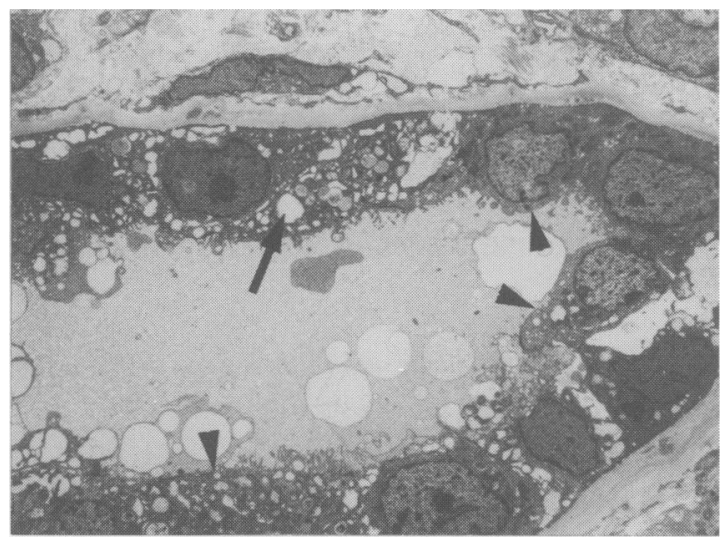

Figure 2 Proximal renal tubule with cytoplasmic vacuolation (arrow) and partial loss of brush border (arrow heads). Electronmicrograph $\times 1600$.

\& Coburn, 1974). Hypovolaemia was not thought to be present in any of the cases reviewed. Renal vein thrombosis is not uncommon in the nephrotic syndrome (Llach et al., 1977) and is another cause of renal failure. It was excluded by venography in all our patients except no. 4. However, it is interesting that despite negative venography, two patients (nos. 3 and 5 ), had histological evidence of intrarenal venous thrombosis affecting small vessels. This pathogenetic mechanism should be looked for and treated appropriately when recognized.

It has been proposed that acute renal failure is more likely to occur in nephrotic kidneys made ischaemic by hypertension and atherosclerosis (Esparza et al., 1981). We therefore note that our patients were elderly (range $58-83$ y), 2 were known to be hypertensive and $3 \mathrm{had}$ been on substantial doses of analgesics and/or non-steroidal anti-inflammatory drugs for years (Table II). These agents are known to affect intrarenal blood flow via action on prostaglandin synthesis (Steward et al., 1982). We were concerned

Table I Review of 36 cases of acute renal failure associated with the nephrotic syndrome due to minimal glomerular lesions

\begin{tabular}{lccc}
\hline Author & No. of cases & $\begin{array}{c}\text { No. achieving } \\
\text { full recovery }\end{array}$ & Duration of support \\
\hline Chamberlain et al., 1966 & 4 & 2 & $1-4$ months \\
Connolly et al., 1968 & 3 & 3 & $1-4$ weeks \\
Raij et al., 1976 & 5 & 0 & No recovery \\
Rose et al., 1978 & 1 & 1 & Not stated \\
Lowenstein et al., 1978 & 14 & 10 & Not stated \\
Hulter \& Bonner 1980 & 1 & 0 & 5 weeks \\
Esparza et al., 1981 & 4 & 4 & $4-8$ weeks \\
Imbasciati et al., 1981 & 4 & 2 & $3-6$ months \\
\hline
\end{tabular}


Table II Review of 5 Southampton patients with acute renal failure complicating the nephrotic syndrome due to minor glomerular lesions

\begin{tabular}{lccccccccc}
\hline No. & Age & Sex & Drug history & $\begin{array}{c}\text { Creatinine* } \\
\mu \text { mol/l }\end{array}$ & $\begin{array}{c}\text { Albumen* } \\
\mathrm{g} / \mathrm{l}\end{array}$ & $\begin{array}{c}\text { Proteinuria* } \\
\mathrm{g} / 24 \mathrm{~h}\end{array}$ & Histology & $\begin{array}{c}\text { Creatinine } \\
\text { maximum }\end{array}$ & $\begin{array}{c}\text { Creatinine } \\
\text { to normal } \\
\text { (weeks) }\end{array}$ \\
\hline 1 & 77 & M & $\begin{array}{c}\text { Fr/Spirono- } \\
\text { lactone }\end{array}$ & 233 & 24 & 21.3 & MP/TD & 1200 & 5 \\
2 & 58 & M & $\begin{array}{c}\text { A for OA } \\
15 \text { y }\end{array}$ & 301 & 29 & 6.2 & MC/TD & 850 & 12 \\
3 & 60 & F & $\begin{array}{c}\text { A/NSAI for OA } \\
19 \text { y }\end{array}$ & 165 & 23 & 12.0 & MP/TD/RVT & 784 & 8 \\
4 & 75 & F & $\begin{array}{c}\text { A/NSAI for OA } \\
16 \text { y }\end{array}$ & 802 & 26 & 5.7 & MC/TD & 958 & 12 \\
5 & 83 & M & $\begin{array}{c}\text { Untreated } \\
\text { hypertension }\end{array}$ & 181 & 26 & 5.8 & MP/TD/RVT & 1700 & Died \\
\hline
\end{tabular}

*On admission; $\mathrm{Fr}=$ frusemide; $\mathrm{S}=$ steroids; $\mathrm{A}=$ analgesics; $\mathrm{OA}=$ osteoarthritis; $\mathrm{NSAI}=$ non-steroidal anti-inflammatory drug; $\mathrm{RVT}=$ intra renal venous thrombosis; $\mathrm{MP}=$ mesangial proliferation; $\mathrm{MC}=$ Minimal change; $\mathrm{TD}=$ tubular damage.

that in 2 patients (nos. 1 and 5) prior treatment of the nephrotic state with frusemide may have had an adverse effect on renal function due to direct tubular toxicity rather than hypovolaemia or interstitial nephritis.

Other mechanisms proposed include redistribution of intrarenal blood flow due to changes in the reninangiotensin system (Esparza et al., 1981; Navar \& Rosivall, 1984) and also tubular obstruction and toxicity due to proteinaceous casts (Imbasciati et al., 1981; Coward et al., 1984) as in myeloma.

The avidity with which the myeloma protein binds to tubular epithelium may be charge dependent and influence toxicity and obstruction (Smolens et al., 1983). It would be of interest to carry out isoelectric focussing of the urinary protein in the patients discussed here. It has been recently suggested that fall in glomerular filtration rate is due to foot process structural changes (Bohman et al., 1984). Finally an allergic interstitial nephritis may occur and be revealed by renal biopsy (Lyons et al., 1973).

We conclude that hypovolaemia and renal vein thrombosis should be excluded in patients with acute renal failure complicating the nephrotic syndrome. All drugs should then be withdrawn and a renal biopsy carried out. If only minor glomerular changes are present, we recommend that, even in the elderly, treatment should be active and include peritoneal dialysis if necessary, as the renal changes are reversible and recovery of renal function is to be expected. Steroids should be given for minimal change nephropathy as is usual practice, but will not affect the duration of renal failure.

We believe that intrarenal venous thrombosis and prior renal ischaemia due to hypertension and nonsteroidal anti-inflammatory drugs are important aetiological factors.

\section{Acknowledgements}

Our thanks are due to Dr R.G. Moore for allowing us to report a patient under his care and to Wendy Hudson for help in preparing the manuscript. 


\section{References}

BOHMAN, S.O., JAREMKO, G., BOHLIN, A.B. \& BERG, U. (1984). Foot process fusion and glomerular filtration rate in minimal change nephrotic syndrome. Kidney International, 25, 696.

CHAMBERLAIN, M.J., PRINGLE, A. \& WRONG, O.M. (1966). Oliguric renal failure in the nephrotic syndrome. Quarterly Journal of Medicine, 138, 215.

CONNOLLY, M.E., WRONG, O.M. \& JONES, N.F. (1968). Reversible renal failure in idiopathic nephrotic syndrome with minimal glomerular changes. Lancet, i, 665 .

COWARD, R.A., DELAMORE, I.W., MALLICK, N.P. \& ROBINSON, E.L. (1984). The importance of urinary immunoglobulin light chain isoelectric. Clinical Science, 66, 229.

ESPARZA, A.R., KAHN, S.I., GARELLA, S. \& ABUELO, J.G. (1981). Spectrum of acute renal failure in nephrotic syndrome with minimal (or minor) glomerular lesions. Laboratory Investigation, 45 (6), 510.

HULTER, H.N. \& BONNER, E.L. (1980). Lipoid nephrosis appearing as acute oliguric renal failure. Archives of Internal Medicine, 140, 403.

IMBASCIATI, E., PONTICELli, C., CASE, N., ALTIERI, P., BOLASCO, F. \& MIHATCH, M.J. (1981). Acute renal failure in idiopathic nephrotic syndrome. Nephron, 28, 196.

KOPPLE, S.D. \& COBURN, M.D. (1974). Evaluaton of chronic uraemia; importance of serum urea nitrogen, serum creatinine and their ratio. Journal of the American Medical Association, 227, 41.
LLACH, F., KOFFLER, A.,FIWCK, E. \& MASSRY S., (1977). On the incidence of renal vein thrombosis in the nephrotic syndrome. Archives of Internal Medicine, 137, 333.

LOWENSTEIN, J., SCHACHT, R.G. \& BALDWIN, D.S. (1978). Renal failure in minimal change nephrotic syndrome. Proceedings of American Society of Nephrology, 22A.

LYONS, H., PINN, V.W., CORTRELL, S., COHEN, J.J. \& HARRINGTON, J.T. (1973). Allergic interstitial nephritis causing reversible renal failure in 4 patients with idiopathic nephrotic syndrome. New England Journal of Medicine, 288, 124.

NAVAR, L.G. \& ROIVALL, L. (1984). Contribution of the renin-angiotensin system to the control of intrarenal haemodynamics. Kidney Internatonal, $25,857$.

RAIJ, L., KEANE, W.F., LEONARD, A. \& SHAPIRO, F.L. (1976). Irreversible acute renal failure in idiopathic nephrotic syndrome. American Journal of Medicine, 61, 207.

ROSE, B.D., SCULLY, R.F., GALDABINI, J.J. \& MCNEELY, B.U. (1978). Case records of the Massachusetts General Hospital. New England Journal of Medicine, 299, 136.

SMOLENS, P., VENKATACHALAM, M. \& STEIN, J.H. (1983). Myeloma kidney cast nephropathy in a rat model of multiple myeloma. Kidney International, 24, 192.

STEWARD, R.B., HALE, W.E. \& MARKS, R.G. (1982). Effects of non-steroidal anti-inflammatory drugs on renal function in the elderly. Southern Medical Journal, 75, 824. 